\title{
Cities without slums and the right to the city: slums in Subsaharan Africa
}

\author{
Nadia Albuquerque and Manuel Correia Guedes* \\ Instituto Superior Técnico, University of Lisbon, Portugal
}

Received: 27 March 2021 / Received in final form: 16 June 2021 / Accepted: 18 June 2021

\begin{abstract}
This paper discusses the issues unravelled by The UN's Cities without Slums Campaign which has been inappropriately communicated across Africa as a project to eradicate slums. Focusing on the Sub Saharan capital of Angola, Luanda. The theme equally explores the 3S's concept in Architecture - Social, Sustainable and Standard solutions - aiming to develop a Social Housing Program, called MUSSUS, in the context of UN-HABITAT and Proficient-EU concepts of slum-upgrading, including bioclimatic design and communal work. The concept of ZEB house is also introduced, including renewable energy systems, and passive design techniques. Mass-construction of houses is achieved, by modular standardisation, but providing adaptability to each family' needs. The main goal is to provide the community with the tools to change their environment, significantly improving quality of life.
\end{abstract}

\section{Introduction}

Currently, architecture is failing to respond to the issues of informal settlements - slums. Slums are today a heavy reality in the developing world - where the rural exodus phenomenon hampered the immigrant population integration by the urban planning process. Impoverished settlements have become a dominant reality in emerging cities, as the urban growth gains momentum, urging great scale in situ slum-upgrading programmes. Today, we can identify two main schools of thought, in terms of approaches on solutions for slums: 'Cities Without Slums' in Africa [1] and 'Right to the City' in Latin America [2]. Both parties confront one another since 'Cities Without Slums' endorses slum demolition and eviction, opposing proactive and participatory actions, which are the basis of the 'Right to the City' campaign [3]. The experience of African countries demonstrates that slum clearance is not a solution to their proliferation - since the population has no means to resettle appropriately - resulting in their displacement rather than elimination, thus forming an endless vicious cycle.

There is still a significant lack of information on sustainable urban and building design for slum renewal in the African context. As environmental awareness becomes

\footnotetext{
* e-mail: manuel.guedes@tecnico.ulisboa.pt
}

the core topic of our century, it is important to associate the refurbishment of slums with mainstream sustainability practices and policies. In addition to avoid the recurrence of inappropriate sustained practices, ignorantly considered ideal. Is it conceivable the upgrading of progressive slums in Sub-Saharan Africa that can solve its environmental and quality issues while adapting its formulation to actual and upcoming needs?

The research process started with the consultation of selected bibliography to improve the knowledge on slums, social issues, and community programmes existing in other in developing countries, with conditions similar to Angola. A field work was also carried out on Luanda's musekes, involving questionnaires and interviews. Together with the analysis of case studies based on the 3S's architecture Social, Sustainable and Standardised - these steps served as relevant references in developing the final project. The ECOTEC and VELUX software were used assess energy and environmental performance, leading to an optimized modular prototype.

\section{Framework}

\subsection{Overpopulation}

Indeed, Srivastava and Singh [4] emphatically state that: "Migration from rural areas is the root cause of increasing slums". 
Nonetheless, the overpopulation and economic injustice concerns present in Africa make slums an acute problem with unprecedented dimensions. Although the continent is not alone in facing such challenges, is certainly at the forefront of the struggle [5]. The numbers of people living in slum conditions are still growing corresponding with the population increase. Joan Clos, executive director of UN-HABITAT, states that Africa "as the fastest urbanising continent in the world, is not only confronted with the challenge of improving the existing slum dwellers, but also the challenge of preventing the formation of new slums" which is associated with population growth [6]. According to the United Nations by 2030, half of Africa's population will live in cities and two-thirds of that growth will take place in slums. [7]. For instance, Kinshasa is the fastestgrowing city in Africa, expecting a $46 \%$ population increase (around 4 million people) adding to its population, in 2010, of 8.7 million. However, the cities of Abuja, Bamako, Luanda, Lubumbashi and Nairobi are all expected to surpass these numbers and grow by between $47 \%$ and $50 \%$ in the next decade, while the cities of Dar es Salaam, Kampala, Mbuji-Mayi and Niamey are projected to grow between $50 \%$ and $57 \%$ [6].

Currently, many African countries are still struggling to reverse the tide of slums, even though most of them have managed to impact their living conditions substantially. Which is the case of Egypt, Libya, Morocco that have nearly halved their total number of urban slum dwellers, and Tunisia that has eradicated them completely. Furthermore, Ghana, Senegal and Uganda have managed to reduce urban slum populations by $20 \%$, and $75 \%$ of Nigeria's population that lived in slums in 1990 reduced to $61.9 \%$ in 2010. Similarly to South Africa, where slum numbers dropped from $46.2 \%$ to $28.7 \%$ of the population [6]. The prominence given to urbanisation as the driving force behind the proliferation of slums in Africa could indeed be attributed to the continent's phenomenal urban transition. In 1950, $14.5 \%$ of the population of African countries resided in urban areas; by 2007, the level of urbanisation increased to $38.7 \%$ [8]. A major consequence of this demographic shift is the urbanisation of poverty whereby the concentration of poverty is moving from the rural areas to urban centres [9].

Finding ways to improve slums will be one of the most demanding problems of the 21st century for African governments [7].

\subsection{Colonialism and duality}

The issue of slums that affects the continents of South East Asia, South America and Africa, are all marked by a common event in history - which is the Colonisation ${ }^{1}$ of their territory. Before colonisation, Africa had its own forms of commerce, science, art and other measures of

\footnotetext{
${ }^{1}$ In the preface of "Colonialism: A Theoretical Overview", [10] defines Colonialism as "a relationship between an indigenous majority and a minority of foreign invaders (...) the lives of the colonized people are made by the colonial rulers for a distant metropolis interest. Rejecting cultural compromises, the colonizers are convinced of their own superiority (...) to rule.
}

civilisation. The colonist nations brought the concept of three Cs: Commerce, Civilisation and Christianity. As followed, the western way of living was imposed and branded as an elevation to the state mankind existed in Africa. Colonisation reshaped the whole structure of Africans way of life; economical, social, philosophical and politically. Therefore, many of Africa's current issues are inherited from that [11]. Furthermore, beyond the knowledge transmitted occasionally from colonialists to the indigenous African population, all surplus from production activities and natural resources were harvested and expatriated. Without colonialism and its consequences, Africa would more likely have developed differently from what it is today - through trade, knowledge-sharing and a move towards industrialisation - in line with the Industrial Revolution. More importantly, Africa's riches would have remained in Africa and expectantly used to develop the continent's infrastructure [12].

A large majority of the problems associated with the actual structure of metropolises in Africa - where the existing slums are poorly built - is associated with the Africans lack of connection with ancestry conception and construction knowledge, which is organically crafted. In the meantime, the western conception standards are largely adopted, forcedly imitating the European models the acculturation process endures after independence - as these are seen to be the most contemporary and correct way of practising architecture. This pattern disregards to acknowledge that architecture should be shaped by its environment and cultural lifestyle. Moreover, as noted by Mr. El Hadj climate change will interact with urbanisation in unpredictable ways [13]. This scenario could potentially make Africa the most modern-conscious continent in the world. If only the continent, as a whole, avoiding the same mistakes - instead of emulating the western models indiscriminately - they could evolve and accomplish better. Since climate change is proven imminent as it is, sustainability is the fresh model of the future, and as so, is becoming more and more implemented everywhere. Therefore, Africa as a continent could become a pioneer in setting a great example to the world.

\subsection{Slum spreading and disparity}

The global assessment of slums undertaken by the [14] shows that 828 million or $33 \%$ of the urban population of developing countries resides in slums. In sub-Saharan Africa, $62 \%$ of the urban population resides in such settlements [9]. African cities tend to be sprawling and cardependent, however, the vast majority of Africans cannot afford cars. In order to maintain affordable housing close to their source of income, people are often forced to remain in slums, this dynamic explains why slums often sit next to staggering wealth [7]. The ever-widening gap between rich and poor is symbolised by the disparity of the living social, political and economic environment. Which is reflected in the contrasting urban forms - exclusive gated communities developing side by side with slums (UN-Habitat, 2015). A recent report advises African countries to plan their cities, in order to avoid mega-slums and vast areas of deprivation developing across the 
continent. Since the current "pattern is (...) oceans of poverty containing islands of wealth.", conditions in African cities are now the most unequal in the world [6]. Over the past 50 years one can distinguish four basic phases in the approach to slums [15];

\section{$1950 \mathrm{~s}-1970 \mathrm{~s}$}

- The destruction of slums was justified by urban managers by appealing to the ideologies of modernisation and decolonisation. This radically destructive approach assumed that the existence of slums was only provisional, a consequence of a transitional process generated by a strong rural exodus [15].

\section{0s-1990s}

- International organisations such as the World Bank and UNICEF promoted the upgrading of slums as a strategy of developing informal settlements. This new strategy pretended to reaffirm the rights of slum dwellers to 'normal' forms of citizenship. The World Bank's support for slum upgrading owes much to the work of John Turner [16], whose had argued based on field observation in Peru, that the solution to slums was not in their demolition, but in improving the environment. If governments could improve the sanitary conditions and environmental quality of slums, then residents given their organizational skills and resourcefulness would gradually improve their houses, especially when encouraged by the security of tenure [16]. The adoption of slum upgrading strategies marked a radical change in official attitude towards slum and informal settlements. However, the extreme complexity of public policies and population increase made such measures difficult.

\section{0s}

- The growing consciousness of environmental problems led to a sharper focus on extreme environmental degradation in slums and the resulting risks for their inhabitants. Strategies of slum rehabilitation and resettlement were meant to integrate the concerns regarding pollution, diseases and high- risk lands [15]. In 1999, the World Bank and UNCHS (Habitat) formed a new organisation, Cities Alliance, aiming African country governments on the need to upgrade their informal settlements and to accommodate slum-upgrading within city developing strategies [3].

\subsection{Gentrification: a vicious cycle?}

\subsubsection{Why cannot slums be cleared?}

African governments often see slums as an eyesore and the land is regularly claimed as State's property. Consequently, people are simply evicted and expected to find new homes. Yet, when slums are demolished, other ones become more crowded, as new housing is often too expensive or isolated from services for slum residents to benefit [7]. According to Sumila Gulyani, a World Bank researcher, slums tend to improve when their residents have an incentive and the money to invest [17]. If people either owned or rented their property for long periods of time, they would improve and maintain their surroundings.
The problem with many African slums, she states, is that people rarely live in one place for more than a few years [7].

Is well noted that the slums are not going to solve themselves, and the governments' compliance will result in the propagation of slums - due to urban population density growth. However, the refurbishment of excluded areas often leads to the gentrification ${ }^{2}$ of informal settlements. This is a common and controversial topic in politics and in urban planning, as it improves the material quality of a neighbourhood, while also forcing the relocation of established residents and businesses seeking lower-cost housing and stores [18]. Despite increasing the attraction to the related infrastructure, the material investment can lead to population displacement. This issue is dominating the debate about gentrification - which is promoting new discussions about progressive approaches - that can fairly distribute the benefits of urban redevelopment strategies [19-22].

\subsection{Slum upgrading and slum eradication}

Slums have been portrayed as institutional failures in housing policy, public utilities, local governance and secure tenure. Over the past five decades, authorities in African countries have adopted several strategies to tackle the informal settlements issue. These approaches include; forced eviction and demolition; resettlement or relocation; slum upgrading programmes; and most recently, the adoption of enabling strategies [9].

In turning a blind eye to slums, governments pursued a programme of low-cost housing, as a strategy for meeting the needs of low-income households. The belief was that such programme - sustained by high and steady economic growth - will result in the elimination of slums. Despite its laudable objectives, the programme failed to meet the housing needs of its intended beneficiaries. Firstly, very few houses were built in relation to the existing deficit. Secondly, the houses built were unrealistic of high standards, and thus very expensive for low-income families; such houses had to be retargeted to middle and highincome households to ensure cost recovery. Thirdly, in many countries, the programme was bedevilled by the proliferation of fraudulent practices during various phases of implementation [9].

In comparison to previous slum strategies, upgrading programmes occurs with minimum loss of physical assets; disruption of livelihoods and social support systems. A review of slum upgrading programmes in Africa over a 30year period reveals certain fundamental shifts. Although upgrading programmes have produced some impressive results, they have been criticized on several grounds, which include [9]:

- Failing to have a citywide effect;

- Low levels of investment incapable of rectifying decades of neglect and deterioration;

- The adoption of a project-oriented approach that failed to ensure the necessary follow-up maintenance of upgraded infrastructure; hasty planning which allowed

\footnotetext{
${ }^{2}$ Gentrification is a process of renovating deteriorated urban neighbourhoods by means of the influx of more affluent residents.
} 
for little or no input from beneficiary communities, thereby resulting in lack of ownership and reluctance to pay for improved services;

- Inability to address the more fundamental supply constraints of land, finance and building materials; weak institutional and financial mechanism as evidenced by the high dependence on external funding;

- Absence of any clear policy on poverty reduction.

All of these factors have limited the effectiveness of slum upgrading strategies in Africa.

\section{3 'Right to the City' vs 'Cities Whitout Slums'}

In order to institutionalise slum upgrading and rectify its associated problems, the World Bank and UN-Habitat have initiated two major programmes. These are the Cities without Slums (CWS) action plan under the auspices of the Cities Alliance and the Slum Upgrading Facility (SUF) [9]. It is in recognition of the challenges posed by the proliferation of slums, that Target 7.d of the Millennium Development Goals (MDGs) - in association with Cities Alliance - sought to significantly improve the lives of at least 100 million slum dwellers by the year 2020 (UNHabitat, 2003). The slogan 'Cities Without Slums' was launched, however, the 100 million mark only represented $12 \%$ of current slum dwellers, as the African continent is expected double its population every 15 years, such modest target could hardly make a dent on the magnitude of slums $[3,23]$.

In addition to substantially improving the lives of slum dwellers, concerted efforts should be made to provide adequate alternatives to new slum formation by prioritising slum prevention programmes and proactive planning [23]. The 'Millennium Development Goal 7 target Eleven' goal of improving the lives of residents of self-produced settlements is a complex and contradictory theme. The campaign's communication with the slogan "Cities Without Slums", triggered a series of unintended approaches to the initial objective. The central concern is the ambiguity of communication and misinterpretation inherent in the formulation of Target Eleven and the absence of corrective guidance for African countries. The Task Force sought to prevent the interpretation of "Cities Without Slums" as "as a policy to block urban migration and demolish slums" and to promote proactive and participatory approaches [24]. However, the endorsement of slum demolition remained prevalent and even legitimised legislative support for evictions, and a shift towards proactive and participatory steps have been difficult to achieve. In the case of MDG 7 Target Eleven, the normative ideal is that cities should not have slums. Nations adopt and support norms at the international level, resulting in "standard behaviour" between regions. The role of the UN is "to serve as a forum for discussion and creation of norms" [25]. However, the discussion can be limited by the fact that norms have a "prescriptive quality" [26]. This implies that "by definition, there are no bad norms" once accepted or internalised, norms should not be questioned. In the case of MDG 7 Target Eleven, the normative idea is that cities should not have "slums" and the slogan "Cities Without Slums" cannot be promoted without challenging the "Right to the City" norm. The global campaigners, norm entrepreneurs and academics promoting a 'Right to the City', in the first decade of the new millennium, have not taken rigorous issue with the 'Cities Without Slums" norm. Mainly because the 'Right to the City' movement emanates from Latin America where the 'Cities Without Slums' norm did not take root in local politics, contrary to Anglophone Africa and parts of Asia.

The "Right to the City" is an idea and a slogan that was proposed by Henri Lefebvre in his 1968 book 'Le Droit à la ville' and that was recently claimed by progressive social movements, thinkers and local authorities. The rule that there should be a "right to the city" for all was thus developed, and even in countries like Brazil, written in federal law. However, this movement had more influence in Latin America and is completely unknown in Africa. Where government entities declared that following the goals launched by the MDG within the 10-year target, they would join the rest of the world in order to progressively eradicate 'slums' [27]. The interpretation of the MDG Seven Target Eleven has become the norm and standard behaviour in several African countries. In relation to 'slums', economic policy and strategies are driven by the global urgency for cities to compete with each other to attract global investments [28]. In other words, we have two normative languages with opposite interpretations and campaigns, which seek a solution to the same problem. In addition to its contradictory interpretation, the slogan "Cities Without Slums" opposes the formulation of Target Eleven in 2 ways:

- The goal is to improve the lives of people living in slums, improving the homes and conditions where inhabit. Following the concept of slum applied in the 1870s, where British legislation enabled local authorities to rebuild housing [29]. In cities such as Rio de Janeiro, where physical improvement has been practiced on a scale, the improved favelas remain visually distinct from the fabric of the formally planned city, maintaining characteristics that define urban exclusion (e.g. Project Casas Melhoradas, Mozambique).

- The goal admits to improving the life of $10 \%$ of the affected population, even if reached, the remaining $90 \%$ will continue to endure precarious conditions [30-32]. Cities with economic transformation power avoid the modernization of informal settlements, preferring to relocate the oldest informal settlements to the urban periphery. This is a deliberate act, as urban policymakers argue that even modernized 'slums' contribute little to the urban economy when compared to private sector ventures (e.g. GTRUCS, Luanda and KENSUP, Kenya) [33].

3 The Brazilian domestic notion or norm that there should be a 'right to the city' for all dwellers to fully enjoy urban life with all its services and advantages - the right to habitation - as well as taking direct part in the management of cities - the right to participation.

${ }^{4}$ Slogan launched by Cities Alliance to promote progressive measures against propagation of slums. 
The Target Eleven - with the 'Cities Without Slums' slogan - did not follow the trajectory that other MDGs followed from 1995, and remained uninformed by activism against eviction, slum demolition and poorly conceived relocation programmes. Meanwhile, UN has been pressured from its member states to translate its initiative, reforming the conception of the destruction of slums a promoting achievable and measurable goals in order to satisfy member states eagerness for practical results [3].

Currently, the World Bank and UN-HABITAT are actively promoting the security of tenure approach. In particular, UN-HABITAT in 1999, adopted the Global Campaign for Secure Tenure as an advocacy instrument designed to support secure forms of tenure for the poorest segments of the population. The Campaign encourages negotiation as an alternative to forced eviction, and the establishment of innovative systems of tenure that minimize bureaucratic lags and the displacement of the urban poor [34]. There are several benefits associated with the security of tenure approach [35]:

- It addresses the tenure insecurity in established slums, which otherwise would translate into a vicious cycle of construction, demolition, eviction and reconstruction;

- It encourages the provision of urban services that were previously absent;

- It motivates residents to invest and contribute to the management their built environment;

- It ensures social cohesion in cities.

Furthermore, tenure regularisation programmes in developing countries are often limited to a few settlements - which do not guarantee a long-term solution to the proliferation of slums - in order succeed tenure regularisation programmes must be implemented on a large scale [35].

\subsection{Slum-upgrading testimonies}

The mindset shift regarding slums allowed new approaches to emerge. In 2003, the Kenyan government and UN-Habitat signed a memorandum of understanding that led to the Kenya Slum Upgrading Programme. KENSUP aims to improve the infrastructure and housing of 5.3 million slum dwellers in Kenya and in other areas of sub-Saharan Africa [36].

The selected slum was Kibera, and the first step to improve the housing was to replace the existing shacks with modern high-rise buildings, allowing previous owners the possibility of becoming the new holders. Before the demolition process, residents were issued ID cards, which provide them with a right to live in transitional housing set up by KENSUP. When completed the new housing units will still remain unaffordable to some, even though the fees are relatively low. This poses a problem to Kibera residents who know that KENSUP is not a UN handout since it receives allocations from the national budget [36]. However, Kibera dwellers are challenging perceptions by responding to the conditions of slum living with mindblowing innovation. For instance, the farmers are countering the challenge of food insecurity with an unusual form of urban farming - sack gardens - that are filled with manure, soil and small stones to grow kale, spinach, onions, tomatoes, vegetables and arrowroot. Likewise, the youth have used graffiti as a response to the threat of political violence in the slum. In 2013 a youth art project called "Kibera Walls for Peace" pre-emptively spray-painted 10 carriages of a commuter train and painted a series of public murals in high-profile locations around Kibera, all aimed at easing tensions between different ethnic and political groups and encouraging peace [36]. Upgrading Africa's largest slum, Kibera, has taken more than a decade, but the process is changing the conversation about how to handle informal urban settlements. In a sense Kenya has paved a way, setting a good example, for other sub-Saharan countries. As the government of Niger has established a $\$ 3$ million budget line for informal upgrading and Ghana is following suit and finalising a framework for a national slum-upgrading program - with a priority focus on its capital Accra [36].

Similarly, the Angolan Government is currently working in improving the slums - musekes - of its capital, following the 2014 Master Plan of Luanda (PDL). The Technical Office for the Urban Reconversion (GTRUCS) of Sambizanga and Cazenga musekes is one of the qualified and active entities in the process of implementing the PDL, which revealed the motivations and future long-term investments of the Provincial Government of Luanda, and mainly seeks to solve the problems of shortage of adequate infrastructures, basic sanitation, road and pedestrian circulation, public space and housing. The irregular settlements, located on the outskirts of the city centre, are defined as the most critical areas to intervene, firstly because its proximity to the centre is convenient and secondly because these slums represent the highest urban density of Luanda [37].

The strategy defined by GTRUCS is very similar to the KENSUP one, which is the rehabilitation of slum areas by replacing the faulty dwellings with vertical constructions that can accommodate more people - in order to respond correctly to the population density. As well as providing the necessary infrastructure, services and recreation. Moreover, the GTRUCS approach is largely described in the next chapter.

\section{Field work}

The 40 years combination of colonial and civil wars in Angola impacted the actual demographic structure of the country. Since a large part of the population was forced to leave their areas of origin, causing migration from rural areas to urban, resulting to a drastic population growth in cities. In addition to being the province with the highest number of inhabitants [27\% of the total population], Luanda is also the city with the highest population density with 347 inhabitants per square kilometre (INE, 2014: 31). Currently, about $60 \%$ of the population of Luanda is presently living in Slums - an estimated figure of 6 Million people.

Luanda has been experiencing "a diversified spatial distribution presenting denser areas than others, which have shaped the current urban duality of the city". (Amado, 2003). The centre grows vertically, but is less dense than the boundary which grows horizontally. The concerns that troubled the original musekes, nearest to the centre, are augmenting since these informal constructions are continuing to spread. Musekes vary in types, forms, size and location, subject to different land tenure, densely or 


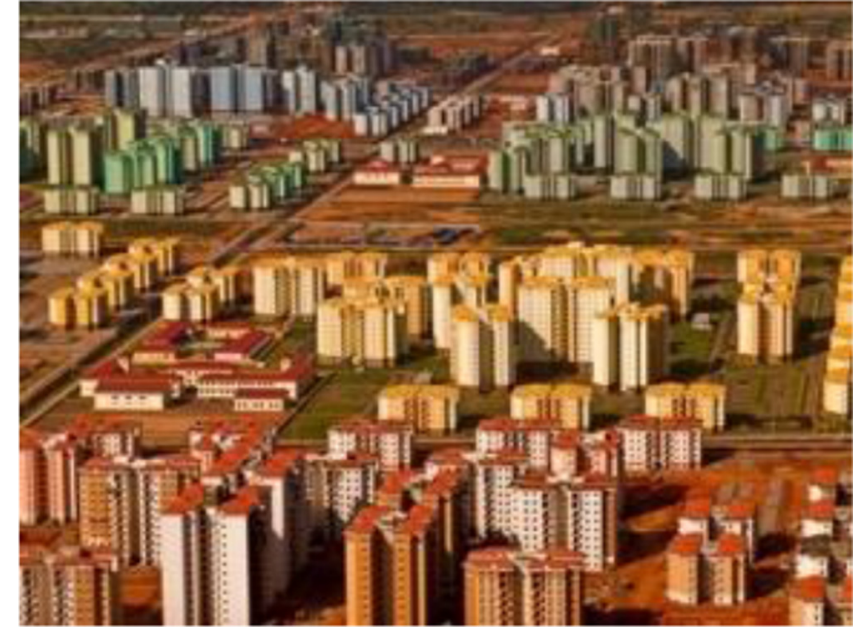

Fig. 1. Township settlements. [s: VERANGOLA].

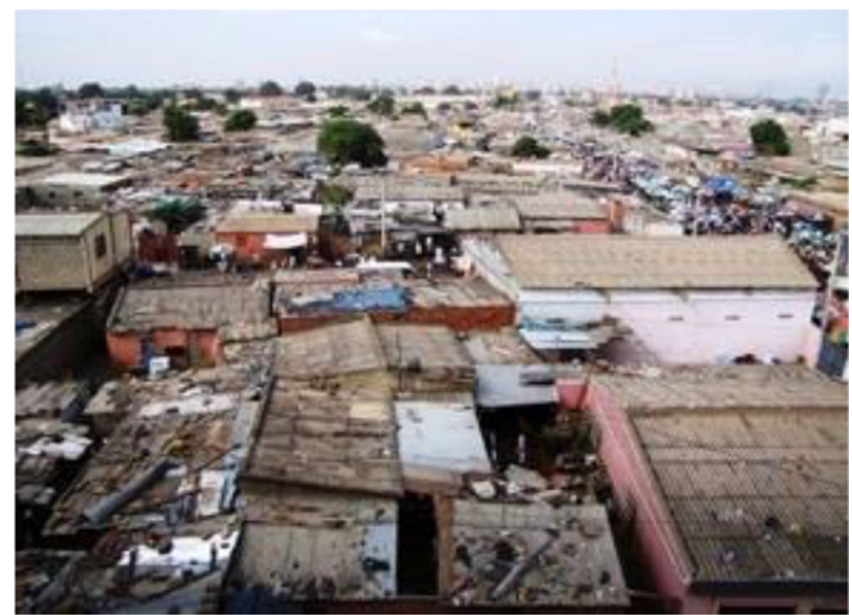

Fig. 2. Organised Musekes. [s: @mauro_s3rgio].

sparsely occupied, with or without street patterns. Given that different contexts houses a variety of slum typologies, it is clear that there is not an international feature [38]. It's undeniable the understanding of museke's exclusion, since its bodily characteristics drastically differs from the planned urban centre of Luanda [39]. Recently, the Development Workshop (2005) classified a series of these settlements, however we will briefly focus on;

- Township Settlements; e.g. Kilamba (Fig. 1) are post civil war plans, developed by the Provincial Government in order to build large-scale residential areas. Located on the edge of urban expansion, the buildings are predominantly vertical, in order to accommodate more families. - Organized Musekes; e.g. Bairro Operário (Fig. 2) are social housing projects developed in the colonial period, where residential areas are built as an extension of the city center. This plan also presented deficiencies concerning foundation infrastructures or services.

- Old Musekes; e.g. Sambizanga (Fig. 3) are residential areas developed without urban planning, defined by the organic layout of the buildings, narrow streets that hinder circulation and higher densities.

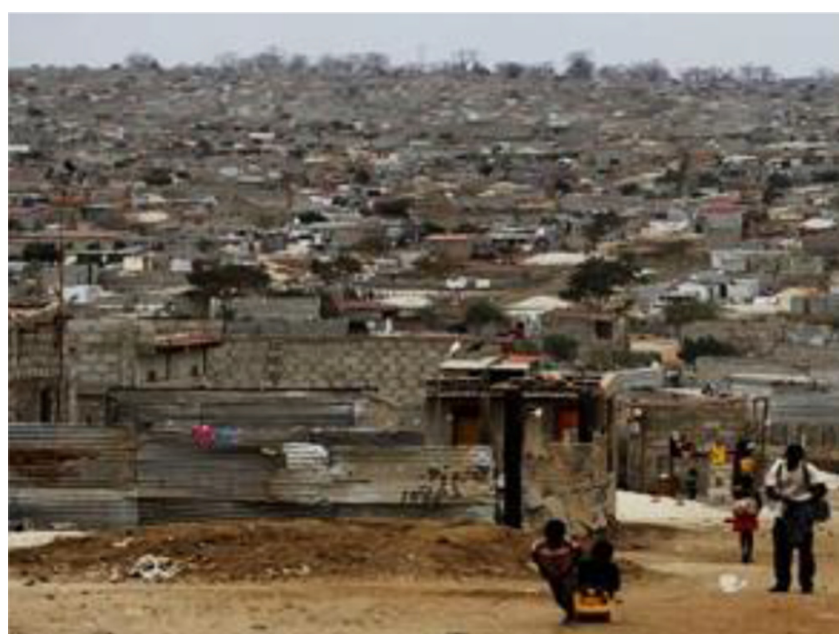

Fig. 3. Old Musekes. [s: Angola Bela].

For centuries architecture responded to social issues in a way that crafted solutions that improved the living space within cities. This sense of altruism is somewhat lost, in developing countries, since there is a lack of compromise in funding the slums crisis. Slums started to develop decades ago, but still remain a contemporary problem, even worsening because of the demography boom in urban areas. In order to solve this problem is necessary to embrace progressive ideologies and adapt them into the conception of new social housing programs. The following sub-chapters present the conclusions gathered after a fieldtrip visit to one of Luanda's main governmental entity which is responsible for the reconstruction of local musekes, as well as the author's proposal for different building solutions that emboldens the concepts of the 3S's - Social, Sustainable and Standardised.

\subsection{Gtrucs visit report}

A journey to the city of Luanda was prepared, with the objective of surveying the critical areas described - so as to verify its actual state - through photographic records and questionnaires. Resuming these experiences with specific reports; the first to the Rehabilitation Centre of Sambizanga (to make aware of the interventions been implemented in musekes currently by the Government), the second and third subjects are visit reports of a regular Bairro Operário - and a irregular - Rangel - musekes.

The Technical Office for the Urban Reconversion of Sambizanga and Cazenga musekes is one of the qualified and active entities in the process of implementing the Luanda Master Plan which policies call for reconstruction of musekes consequently relocating residents to township settlements. Their actual system strategy relies on 4 important phases;

- Phase 1: Delimitation (The first step is to define an area - close to the intervention zone - with moderate dimensions, which would then allow the design of the housing plan).

- Phase 2: Registration (The areas to demolish are defined in phases - giving priority to areas of risk and urgency of relocation). 


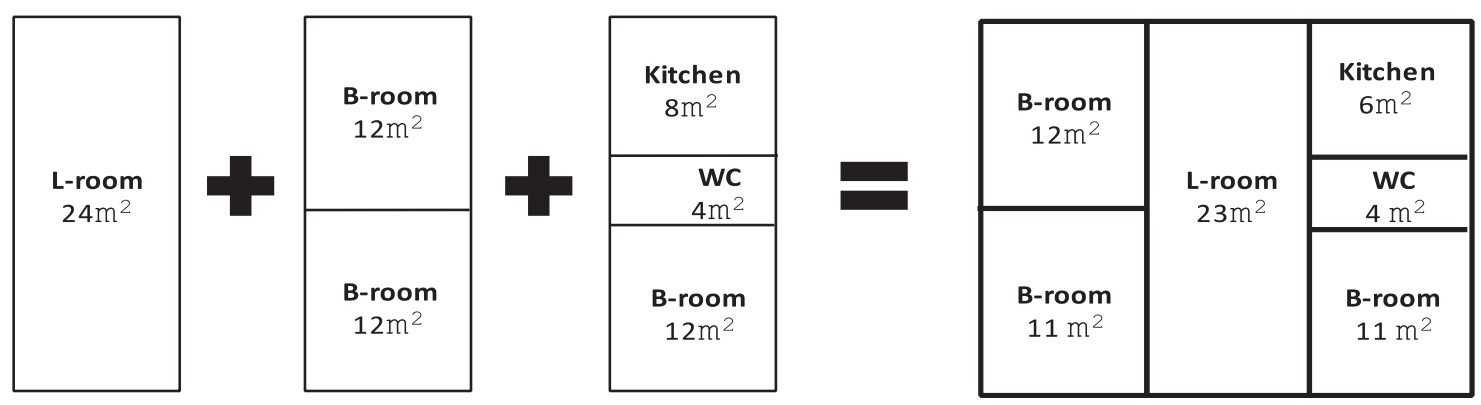

Fig. 4. Areas disposition. Source: Author.

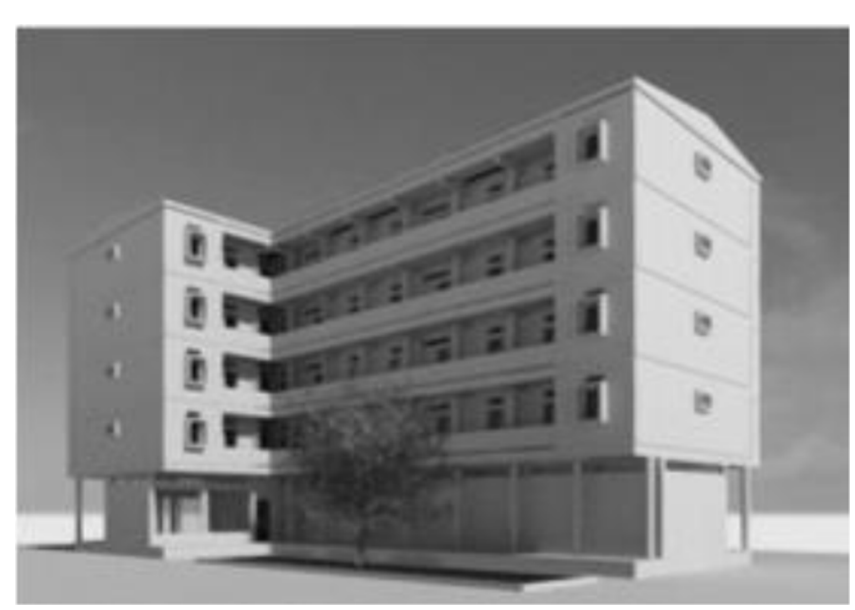

Fig. 5. Social housing prototype. [GTRUCS].

- Phase 3: Construction (The social housing model is vertical - since the high density of musekes demands the creation of additional dwellings - consequently housing more families in less space.).

- Phase 4: Reintegration (The real challenge for these families will be to live in a neighbourhood built for the purpose of relocation, away from their previous home and their daily lives).

The demand of building the maximum number of dwellings at the lowest possible cost implies restraints in the decision of the minimum building areas. Accordingly, is defined the criterion of 2 people per room, considering that a two-bedroom apartment can accommodate up to four people. In the conception of the apartments the accessibility adopted is by external galleries, which functions as an extension of the residence, providing space for activities to be carried out abroad, as well as space for interaction among neighbours (Fig. 4).

These galleries also establish a connection with the surrounding public space and constitutes an element of shading (Fig. 5). The 3-bedroom apartment, which most meets the needs of households, is a spatial module of $3.00 \times 8.00\left(24.00 \mathrm{~m}^{2}\right)$, that overlaps the structural module, which allows different responses to various program units. Despite the tiny size of the residence, the living-room holds a dimension adjusted to the Angolan families reality, who meet frequently on weekends. It seeks to reproduce a context of collective housing, a courtyard atmosphere, characteristic of the Angolan modus vivendi. To conclude, The unplanned city - musekes - were built under insufficient knowledge - by people themselves - resulting in problematic areas with severe sanitary conditions. The solutions being implemented by the GTRUCS are motivated by relocating the people living in musekes to new centralities - township settlements. Since there is a notorious resistance by the population in maintaining the residence close to the centre, the in-site upgrading improving the existing infrastructures and rebuilding the degraded constructions - would be an optimum solution. Finally despite of sharing many of the obstacles, the orthogonal layout of regular musekes, facilitates the concept of in-site rehabilitation, on the opposite, the irregular musekes, which organic layout presents greater issues related to accessibility, circulation and urban density, that would demand a higher amount of demolition and planning in the process of rehabilitating the current structure. For that, both cases require different approaches, that are further developed in the next chapter.

\subsection{Bairro operário visit report}

Identified by the Development Workshop as an organized museke, Bairro Operário (Fig. 6) represents a cluster of degraded buildings with great rehabilitation potential. Since its regular road system facilitates the intervention of new infrastructures. Throughout the site's visit, it was evident that the Bairro Operário - although initially intended to be regular - did not maintain the clear lines of its planning. The buildings expanded and invaded the roads organically - according to personal needs - an inevitable consequence caused by the lack of infrastructure in the foundation of the neighbourhood. Thus, the housing blocks became mutable, some resulting on the expansion of existing constructions and other annexes of new residents. The individual constructions display this diversity, as the houses materials quality vary between cement, wooden and steel-sheets. In order to observe where lays the strengths and weaknesses of the urban and lived spaces, it is performed a quick SWOT analysis, which can characterise the structure and morphology of the neighbourhood. Through this analysis is possible to verify a few problematic areas within the neighbourhood, especially the ones closer to the core, where the lack of regulation is more obvious. There is also a lack of designated public spaces and services 


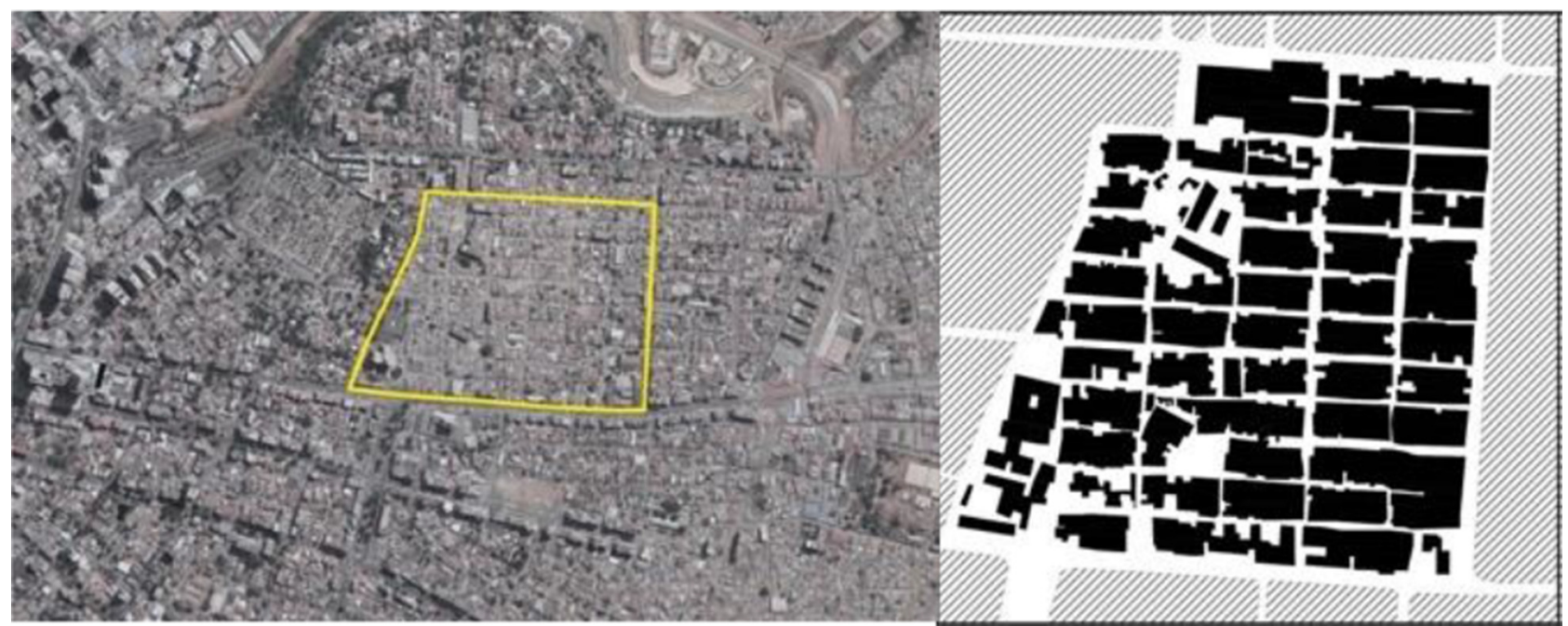

Fig. 6. Bairro Operário location. [GOOGLE EARTH].
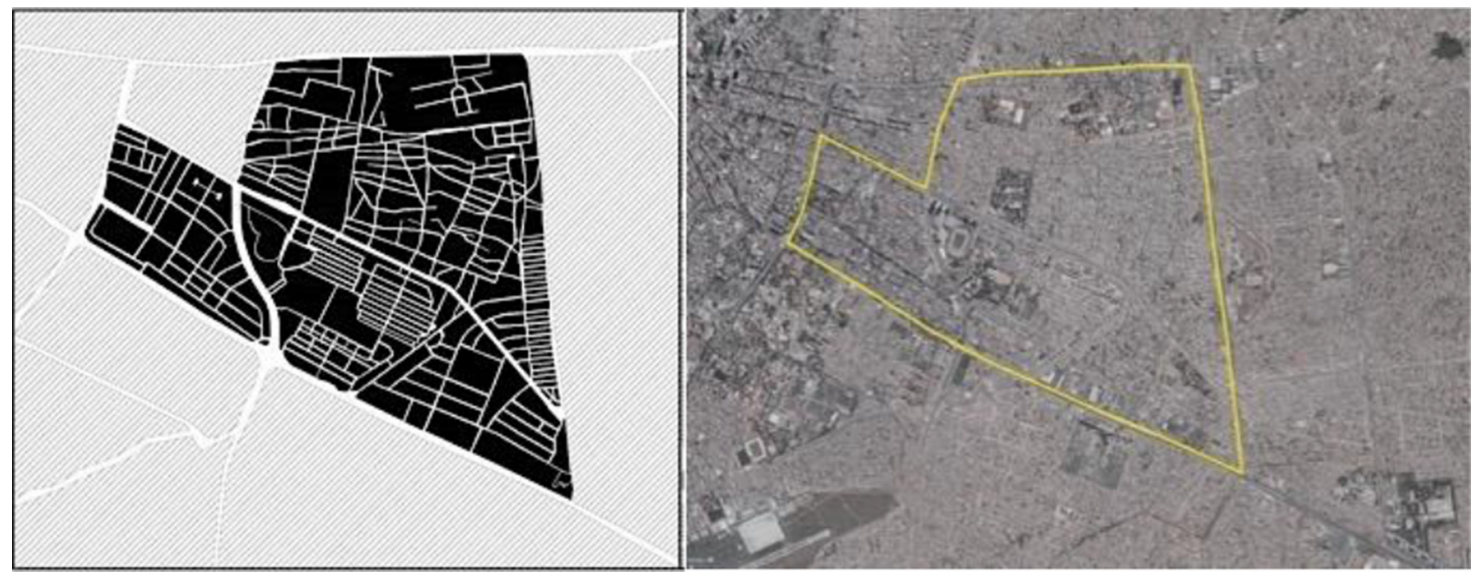

Fig. 7. Rangel location. [GOOGLE EARTH].

for common use, which than translates in the use of the streets - in poor sanitary conditions - for recreation and market trades spots.

During the visit, the inhabitants displayed a great distrust of strangers. Unknown people, who question and move around taking pictures, are seen as a threat to their homes. Since the Government has already undergone registration processes, where several houses were demolished, this process though fell short of expectations due to budget cuts. However, the few inhabitants interviewed agreed about the urgency of new infrastructures, when asked about what they would change in the neighbourhood. This would be the ideal starting point for the development of the remaining complementary structures.

\subsection{Rangel visit report}

Identified by the Development Workshop as an irregular museke - despite its mixed qualities. Rangel's (Fig. 7) irregular lineage is associated with the high population density of the neighbourhood -42 097 inhabitants per $\mathrm{km}^{2}$-which encouraged the development of blocks of gigantic proportions and inhibited the introduction of sanitation and security infrastructures. Throughout the site's visit, it was possible to verify a heterogeneous structure, marked by the proximity to the organized urban centre of Luanda. The neighbourhood gradually becomes organic in relation to its outline neighbours - to the north, west and south - which are regularized. The organized areas of Rangel covers basic sanitation infrastructure although deficient - since the irregular area located in the east of the neighbourhood, supports the scarcity of the same infrastructure.

Unlike many irregular musekes, Rangel is well-found with several services organization, such as; schools, hospitals, colleges, sport centres, supermarkets, shopping, etc. But these services are part of the regularized territory, where there is no discontinuity with the rest of the city, therefore, neglecting the irregular part of the territory. The lack of planning in the neighbourhood, as a whole, represents a great dimension that discourages urban control. In order to be able to configure and adapt to an orderly common neighbourhood, the existing division of the neighbourhood into sub-divisions would have to be 
reinvigorated. The individual constructions are stimulated by population density, since the developed rapidly close to regular buildings - with the initial aim of maintaining the same conformity - but the lack of municipal control led to the construction of extremely dense blocks with unusual dimensions and configurations, which the only access to the core is done through narrow alleys.

Quality of life is tested, and the only way to restore it, is to rehabilitate the whole neighbourhood, creating new streets that regulate circulation, which also facilitate the introduction of infrastructure. The green spaces identified, in the neighbourhood, are of private origin, belonging to backyards and public facilities, such as the courtyard of the Américo Boavida Hospital and the surroundings of the Cidadela stadium. Due to the high density of construction, there's a lack of public open spaces [green or not] for recreation and air renovation, indispensable for Luanda's tropical climate.

\section{Mussus programme}

\subsection{Mussus concept}

The MUSSUS [MUSEKE + SUSTAINABLE $=$ MUSSUS] programme embodies the social housing and urban renewal urgency required in the city of Luanda, Angola. The ideology stems to embrace the community needs and prospects, regarding environmental and economic issues in addition to contribute to a self-sufficient way of building. Adopting the combined concepts of social housing, modularity and sustainable architecture [40,41], that can lead to the transformation of slums in Luanda. Therefore, in order to achieve those goals, the MUSSUS Programme principles are;

- To create a module, that can multiply, adapt and modify embedded in a standard construction, that contemplates the process of spatial evolution. To use passive methods and materials, to reduce the environmental impact.

- To create an intermediary instrument, through self-manipulation, that can turn a concept into matter the MUSSUS form.

- To create a movement of mutual aid practices. A sustainable and self-sufficient mindset that would promote, recycling and maintenance into rehabilitation. Integrate professionals and any expert that can improve the process and experience.

The broad project is to develop a Social Housing Programme, in the context of UN-HABITAT and Proficient-EU concepts of slum-upgrading, passive design and community volunteering work. Introducing the concept of ZEB house [zero net energy], increasing the renewable energy of the construction, through passive design techniques. Assisting the conception of mass-construction houses, by standardisation and schematic module, providing house diversity and enlargement adapting to each family needs. Therefore maximise the energy consumption by economising, the budget costs, through the use of local materials. The line of reasoning is to create a module that must commit to a sustainable configuration and should
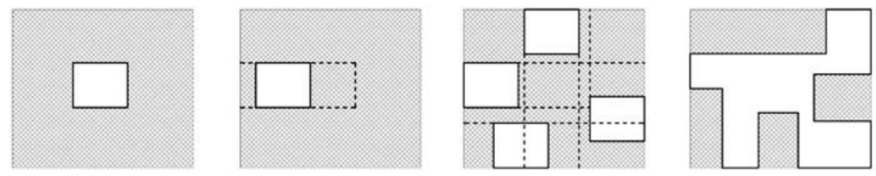

Fig. 8. Regular; Patios, empty and full, movements illustration. [Author].
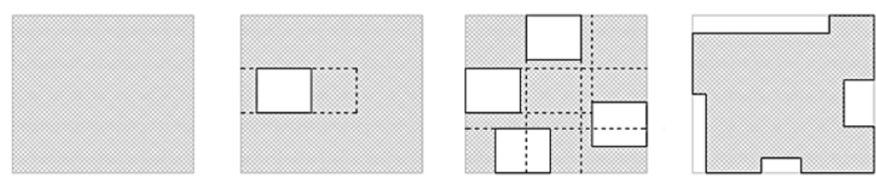

Fig. 9. Irregular; Patios, empty and full, Movements Illustration. [Author].

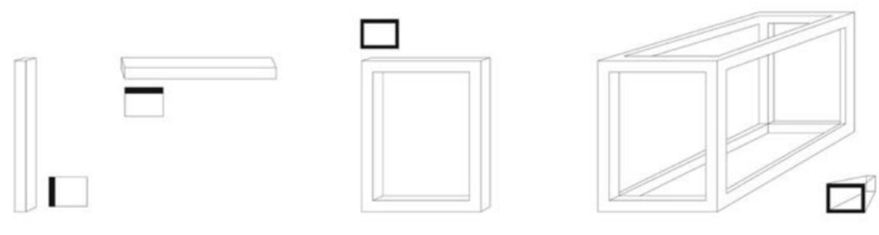

Fig. 10. Structure standard module. [Author].

acquire the characteristics of pragmatic constructions accordingly.

The courtyard model is considered the best option for the climatic context of Luanda. As a principle of bringing diversity, the patio is multiplied, awarding a succession of different solutions for the constructed and open areas. The module concept in the regular case (Fig. 8) consists in arranging blocks around the terrain, thus creating various patios, while in the irregular case (Fig. 9) the practice is cutting patio incisions into a massive block, like a negative imprint.

In the Regular Case, each building block represent a different function, conventional or not, they are decided by the families themselves. However, in order to facilitate this process, is important to define designed spaces with according dimensions. Stipulating the maximum total area of the house, whereas between 150 to 200 square meters, managing the overall budget that is required to stay low-cost. The efficiency of the standard module is only possible if the constructive system follows the same train of thought. The structure base of the houses would be defined by the outline of a cube, pillars and beams (Fig. 10). The filling of structures would then be cement blocks masonry made in real time or even pre-fabricated. The exterior walls should be strategically perforated as to facilitate the passive performance.

The remaining patio spaces would integrate, pathways for crossing and planting spots. Is relevant to sustain the concept of green areas, even in terraces, arranging spaces dedicated to agricultural needs - for a self-sufficient life and air renewal. To adopt an evolutionary spatial module, is necessary the definition of flat roof-tops, that can be adapted into functional spaces. The terraces are the basis 

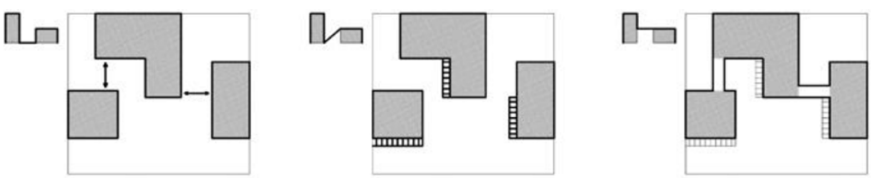

Fig. 11. Stairs and bridges illustration. [Author].

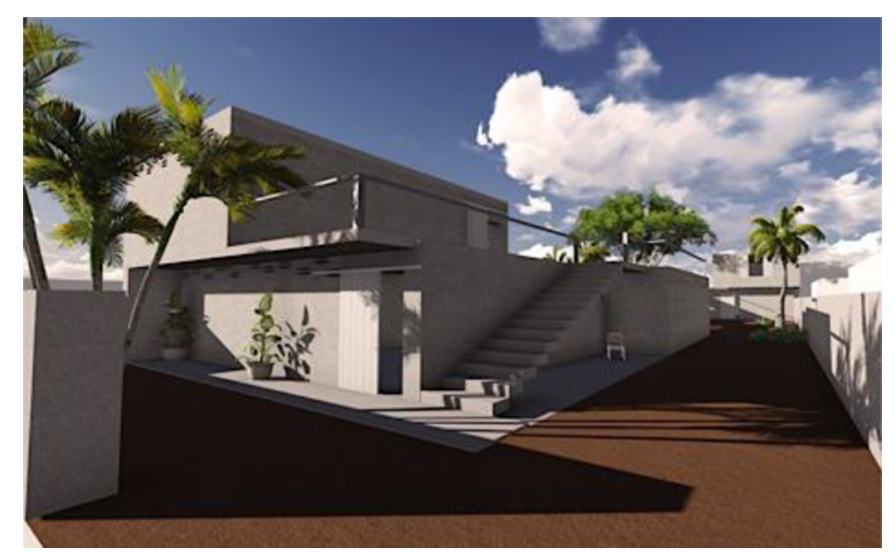

Fig. 12. Model front view. [Author].

for future expansions of the house. The blocks should be put apart, occasionally together, in order to maximise ventilation between and through them. To minimise the construction area, since the blocks are separated, the links - stairs and bridges - are outlining the blocks (Fig. 11).

\subsection{Bioclimatic analysis}

Luanda's location is southwest coast of Africa bathed by the Atlantic Ocean in the West. The Angolan climate is classified as sub-tropical, hot and humid in most of the territory, with a semi-arid and dry sub-humid zone in the south and on the coastal strip up to the Province of Luanda [42]. The climatic context in Luanda demands prudence regarding the radiation levels. Since the year in Luanda is warm all-around, it is necessary to use shading systems and natural ventilation $[43,44]$.

\subsubsection{Regular: bairro operário study analysis}

The regular musekes of Bairro Operário represent one of the greatest potential for in-site slum upgrading, in Luanda, since already displays its streets in a orthogonal urban layout. After choosing a block and house, this procedure was then simulated (Fig. 12) with the Fragoso family. Since the houses must be partially or entirely demolished, in order to adapt the new constructions, there must be located unoccupied sites in the neighbourhood that would stablish an auxiliary structure to house the families while the rehabilitation process is ongoing. This structure, is expected to have around six or more apartments that would shelter families gradually. The acknowledgement of the MUSSUS process were well received, and with my assistance, it was possible to design the structure of a new
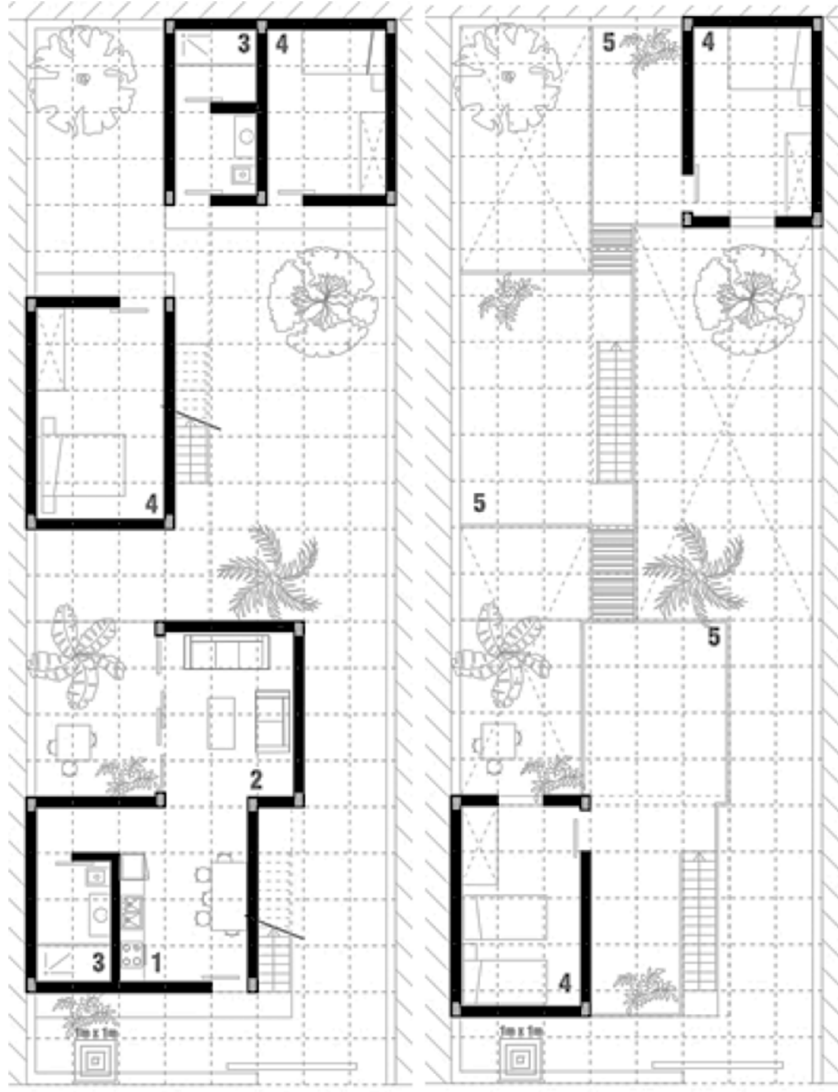

Fig. 13. Regular 1st and 2nd floor plans. [Author].

house guaranteeing the characteristics described by the owner and the rest of the Fragoso family; Two-story construction, A big kitchen area connected to the livingroom, Private patios, 4 bedrooms, At least 2 bathrooms (Fig. 13).

Trough Autodesk Revit, precisely INSIGHT 360, an energy analysis was performed revealing the energy consumption of the construction. This was an exclusively comparative analysis, i.e. to observe how energy consumption would decrease with the use of different passive design strategies: the MUSSUS design concept is fully bioclimatic, i.e. no air conditioning is used. The monthly heating load chart (Fig. 14) analyses the heat loss of each construction element throughout the year. The elements represented bellow the zero mark are defined by the greatest heat loss. Which is a positive result for the construction of the Fragoso family house, since the walls and roofs define the majority of the exposed area. That means that those elements are not maintaining the heat gained during the day, mostly because of the low absorptivity properties of the chosen materials, and the openings in the walls. The higher heat gain impact is the direct solar radiation through the windows was improved with shading systems.

The monthly cooling load chart (Fig. 14) analyses the energy need for cooling of each construction element throughout the year. The heat energy gain of each element are defined above zero, and the most affected elements are 

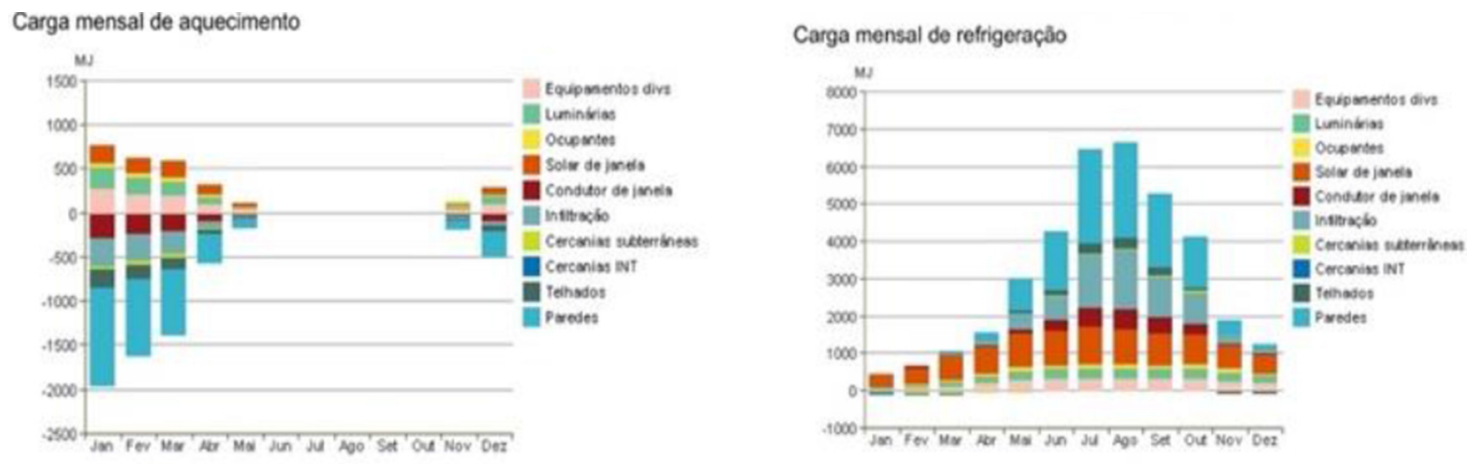

Fig. 14. Monthly heating and cooling load chart. [REVIT].

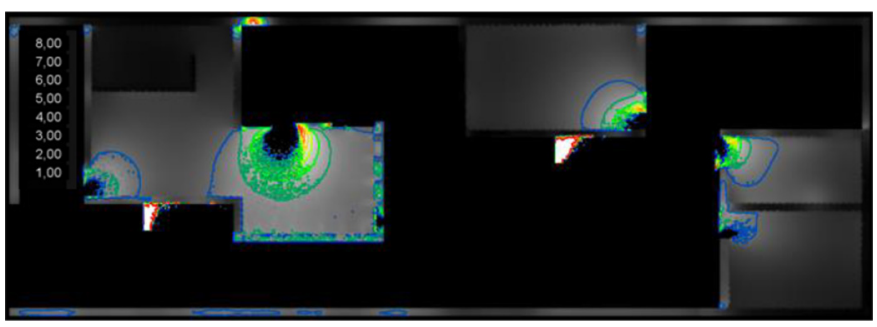

Fig. 15. ISO contour diagram of daylight incidence. [VELUX].

the walls and windows. This chart is a fair representation for the semi-arid climate experienced in Luanda, and shows that the perforated walls are an insufficient element to guarantee the thermal comfortability during the hottest days. However, shading systems, weren't used in the simulation process, which can positively impact the performance of the cooling performance. Especially the introduction of tress and greeneries, that are excellent in shading the walls while improving air circulation.

According to the results it was observed that the cooling systems presented by the perforated walls, demanded less use of active design techniques, such as air conditioning. To further analyse the incidence of radiance (Fig. 15) inside the building, trough VELUX, a plan image was produced displaying the lux levels inside, as represented in the following image, the interior of each compartment transmits a valid performance according to the design, since the doors and windows permit more radiation entry. [The red lines (factor 800 lux) are present in the exposed areas, the green lines (factor 500 lux) are the openings, and blue lines (factor 200 lux) the cooler temperature. The night ventilation simulation was not executed, since the most critical period of the semi-arid climate is during daytime, as the sunlight exposure increases the temperature indoors. However, analysing the wind rose of predominant winds, is possible to verify that they are equally spread throughout all the orientations, thus guaranteeing that perforated walls oriented north, south, east or west - have a good performance of air renewal through cross ventilation.

\subsubsection{Irregular: rangel study analysis}

This museke has a closed morphology the exterior, most of the daily tasks are done within the neighbourhood. The

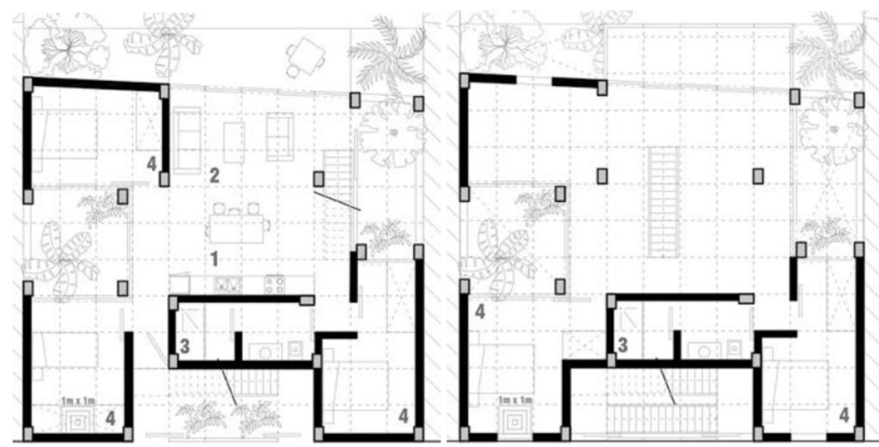

Fig. 16. Irregular 1st and 2nd floor plans. [Author].

chosen block is located near the Rangel nucleus, fifth in the right-left direction (Tunga Ngo Street). The MUSSUS programme supports that the solution to improve the populational density crisis of irregular musekes - which is higher than the regular musekes - is to develop several vertical constructions. The block is divided into subblocks, housing 3-4 vertical housing units, with the limit of 4 floors per building, for the same reasons defined previously by the GTRU. The 1st floor (Fig. 16) and half of the 2 nd floor (Fig. 16) form an apartment (up to $<6$ bedrooms), the other half of the 2 nd floor and the $3 \mathrm{rd}$ floor form another apartment (up to $<6$ bedrooms, and occasionally 4 bedrooms). The purpose of the simulation held for a house in the irregular museke of Rangel was to accommodate 3 large families. The selected site has an area of $22 \mathrm{~m}^{2}-11 \mathrm{~m}$ wide and deep - excluding the courtyards and public areas. The main objectives were to adapt interior patios into all the floor areas, that promotes cross ventilation and improves natural illumination during the daytime.

Similar to the Regular case the results corroborated that the cooling systems presented by the perforated walls, demanded less use of active design techniques, such as air conditioning. An daylight occurrence (Fig. 17) was held, trough VELUX, and the areas with higher radiance incidence are the non-shaded areas as the balconies and entrance stairs. Nevertheless the rest seem to corroborate the expected performance of the drawing plans (Fig. 18). The night ventilation simulation was not executed, since the most critical period of the semi-arid climate is during daytime, as the sunlight exposure increases the temperature indoors. However, analysing the wind rose of wind 


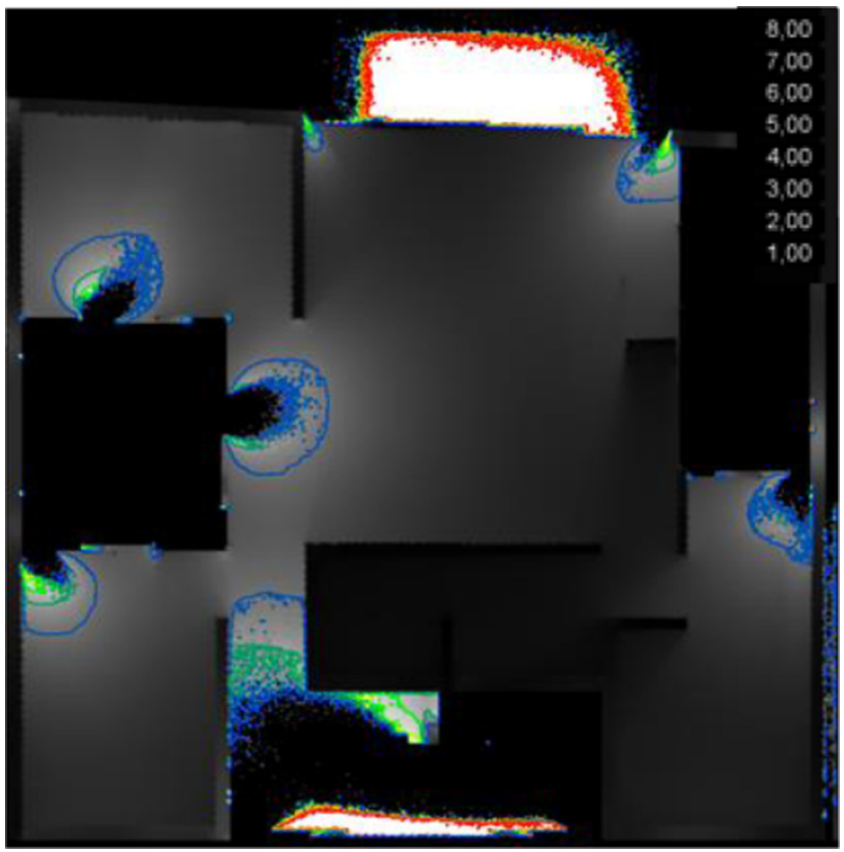

Fig. 17. ISO contour diagram of daylight incidence. [VELUX].
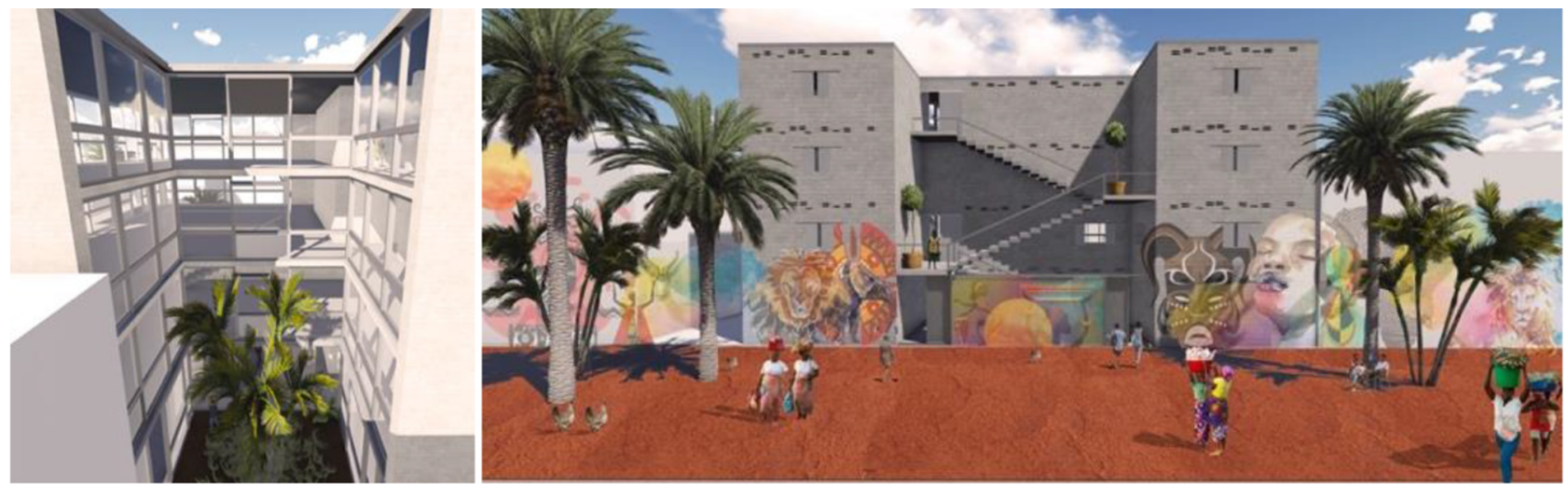

Fig. 18. Model View and Mutual Line Simulation Render. [Author].

velocity orientation, is possible to verify that the wind coming from the west achieves a higher velocity, as westnorth orientation receives the highest velocity range. Consequently, perforated facades oriented west-north can guarantee a better performance of air renewal through cross ventilation.

The irregular musekes represent an enormous challenge in solving the slums crisis in Luanda. Since is mandatory to destruct a great amount of the urban fabric, in order to create new public spaces, re-shape the streets infrastructure and rebuild new housing arrangements. In the definition of the commercial and mutual typologies this is also the perfect strategy - green public spaces and streets with commerce fronts - to connect a city-wide network. The Mutual Line is the designated place for free creative demonstration of the community talents, since is well-noted that colour and street art can change the way a place is lived and perceived from outsiders.

\section{Conclusion}

Although the relevancy of the 'Cities Without Slums' movement in Africa, history and experience indicates that the demolition of slums are not the solution for their propagation. The answer should instead involve inclusive and progressive programmes similar to MUSSUS, that may contribute to the re-definition of the musekes, allowing people to be involved in the conception of their living space, humanizing the importance of their homes. This process bring new ideas, new design solutions, inspiring new space configuration and a tangible 
recommendation plan to existent structures in Luanda, and possibly Angola.

\section{Acknowledgments}

This work was developed in the context of the "Africa Habitat" research project, funded by FCT (National Science and Technology Foundation, Portugal).

\section{Acronyms}

$\begin{array}{ll}\text { CWS } & \text { Cities Without Slums } \\ \text { GCST } & \text { Global Campaign for Secure Tenure } \\ \text { GTRU } & \text { Gabinete Técnico de Requalificação Urbana } \\ & \text { [Urban Rehabilitation Cabinet of Sambizanga } \\ & \text { and Cazenga] } \\ \text { MGDs } & \text { Millennium Development Goals } \\ \text { KENSUP } & \text { Kenya Slum Upgrading Programme } \\ \text { PDL } & \text { Plano Director de Luanda [Luanda's Master- } \\ & \text { plan] } \\ \text { SUF } & \text { Slum Upgrading Facility } \\ \text { UN } & \text { United Nations } \\ \text { UNICEF } & \text { United Nations Children's Fund } \\ \text { UNCHS } & \text { United Nations Human Settlements Programme } \\ \text { WMO } & \text { World Meteorological Organisation }\end{array}$

\section{References}

1. Cities Alliance, - available on: http://www.citiesalliance. org/About-slum-upgrading

2. H. Lefebvre, 'Le droit à la ville, Vers la sociologie de l'urbain', Ellipses, 1968

3. M. Huchzermeyer, Cities with Slums: From Informal Settlement Eradication to a Right to the City in Africa, University of Cape Town Press, Cape Town (2011)

4. A. Srivastava, R.C. Singh, Slums and associated problems: A case study of Bhilai, an industrial city, India, Int. J. Environ. Stud. 50, 51-60 (1996)

5. D. Kilcullen, G. Mills, W. Trott, Discussion paper 5/ 2015 Poles of Prosperity or Slums of Despair? The future of African Cities, The Brenthrust Foundation (2015)

6. J. Vidal, The Guardian, Africa warned of 'slum' cities danger as its population passes 1bn, 2010, https://www.theguar dian.com/world/2010/nov/24/africa-billion-population-unreport

7. The Economist The great urban racket, Exploitation and short-sightedness in Africa's slums, 2017, https://www. economist.com/middle-east-and-africa/2017/04/20/exploi tation-and-short-sightedness-in-africas-slums

8. United Nations World Urbanization Prospects: The 2007 Revision Population Division, Department of Economic and Social Affairs New York 2008, www.un.org/esa/population/ publications/wup2007/2007WUP_Highlights_web.pdf

9. B.C. Arimah, UN-HABITAT, Slums as expressions of social exclusion: explaining the prevalence of slums in African countries. online source: ResearchGate, 2015
10. J. Osterhammel, (author), L. Frisch, Shelley (translator), L. Tignor, Robert (foreword), Colonialism: A Theoretical Overview, 2nd Edn. (M. Wiener, 1997)

11. P.A. Nyoni, This is Africa, What Africa had before colonization, 2015, https://thisisafrica.me/africa-colonisation/

12. B. Tuck, Quora, Was colonization on the whole good for Africa?, 2016, https://www.quora.com/Was-colonizationon-the-whole-good-for-Africa

13. K. Racelma, Africa Renewal Online, Towards African cities without slums Governments set course towards improving poor urban areas, 2012, https://www.un.org/africarenewal/ magazine/april-2012/towards-african-cities-without-slums

14. UN-Habitat State of the World's Cities 2010/2011: Bridging the Urban Divide Earthscan London, 2010

15. F. Lieberherr-Gardiol, Slums forever? Globalisation and its consequences, Eur. J. Dev. Res. 18 (2006)

16. H. Werlin, The slum upgrading myth, Urban Stud. 36, 1523-1534 (1999)

17. M. Majale, Graham Tipple and Matthew French, Un-habitat - Affordable Land and Housing in Africa, 2011

18. L. Freeman, Displacement or succession? Residential mobility in gentrifying neighborhoods, Urban Aff. Rev. 40, 463-491 (2005)

19. Gentrification, online source: https://www.dictionary.com/ browse/gentrification

20. L. Lees, T. Slater, E.K. Wyly, Gentrification, Print. Defines gentrification as the transformation of a working-class or vacant area of the central city to a middle class residential and/or commercial use, Routledge/Taylor \& Francis Group, New York (2008)

21. A. Morisson, C. Bevilacqua, Balancing gentrification in the knowledge economy: the case of Chattanooga's innovation district, Urban Res. Practice, 2018, doi: 10.1080/17535069. 2018.1472799

22. J.L. Vigdor, D.S. Massey, A.M. Rivlin, Does Gentrification Harm the Poor? [with Comments], Brookings-Wharton Papers on Urban Affairs: 133-182 (2002)

23. UN Millennium Project, A Home in the City, Task Force on Improving the Lives of Slum Dwellers Earthscan London, 2005

24. P. Garau, E. Sclar, G. Carolini, A Home in the City: UNMillennium Project Task Force Report on Improving the Lives of Slum Dwellers (United Nations, New York, 2005)

25. F. Giovannini, Towards an intellectual leadership: rediscovering the role of the United Nations in the 21st century. Interface, Plan. Theory Practice 9, 254-260 (2008)

26. M. Finnemore, K. Kathryn Sikkink, International norm dynamics and political change, Int. Organ. 52, 4, 887-917 (1998)

27. L. Sisulu, Speech by LN Sisulu, Minister of Housing, at the occasion of the tabling of the Budget Vote for the Department of Housing for the 2005/06 financial year, National Assembly, Cape Town, 17 May 2005 (Ministry of Housing, Pretoria, 2005). Available at: http://www.info.gov. za/speeches/2005/05051715451004.htm (accessed 14 August 2008)

28. I. Turok, Cities, regions and competitiveness, Regl. Stud. 38, 1069-1083 (2004)

29. P. Garside, 'Unhealthy Areas': Town planning, eugenics and the slums, 1890-1945, Plan. Perspect. 3, 24-46 (1988)

30. UN-Habitat, The State of the World's Cities Report 2006/2007. 30 Years of Shaping the Habitat Agenda (United Nations Human Settlements Programme, Nairobi, 2006) 
31. E. Pieterse, City Futures: Confronting the Crisis of Urban Development (Zed Books, London, 2008)

32. Amnesty International, MDG Summit. World leaders fail to uphold rights of the poorest (Amnesty International, London, 2010). Available online on http://www.amnesty. org/en/news-and-updates/mdg-summit-world-leaders-failuphold-rights-poorest-2010-09-22

33. N. Smith, New globalism, new urbanism: gentrification as global urban strategy, Antipode 34 (2002)

34. UN-Habitat Global Campaign for Secure Tenure: Concept Paper UN-HABITAT Nairobi, 2004

35. A. Durand-Lasserve, Benefits of regularizing informal settlements, Habitat Debate 5 (1999)

36. K. Sebambo, Design Indaba, The Transformation of Kibera from Africa's largest slum to promised land, 2015, http:// www.designindaba.com/articles/point-view/transformationkibera-africas-largest-slum-promised-land

37. N. Albuquerque, MUSSUS The guidelines for the inclusion of Musekes in Luanda, Dissertation to obtain the Master's
Degree in Architecture, IST (Instituto Superior Técnico), Universidade Técnica de Lisboa, 2018

38. UN-HABITAT, Streets as tools for Urban Transformation in Slums - A Street-Led Approach to Citywide Slum Upgrading, Routledge, 2014

39. S. Viegas, Urbanization in Luanda: Geopolitical FrameworkA Socio-Territorial Analysis, 2012

40. R. Nady, Modular Architecture, 2015, https://www.arch2o. com/language-modular-architecture/

41. P. Oliver, Dwellings - The Vernacular House World Wide (Phaidon Edition, 2003)

42. M.C. Guedes, Arquitectura sustentável em Angola: manual de boas práticas. Editora CPLP, Comunidade dos Países de Língua Portuguesa, 2012

43. M.C. Guedes, Bioclimatic architecture in warm climates: a guide for best practices in Africa (Springer, Cham, 2019)

44. M.C. Guedes, Chapter 16-Sustainable architecture in Africa, in: A. Sayigh (Ed.), Sustainability, Energy and Architecture, Case Studies in Realizing Green Buildings, AP Edition (2014)

Cite this article as: Nadia Albuquerque, Manuel Correia Guedes, Cities without slums and the right to the city: slums in Subsaharan Africa, Renew. Energy Environ. Sustain. 6, 24 (2021) 